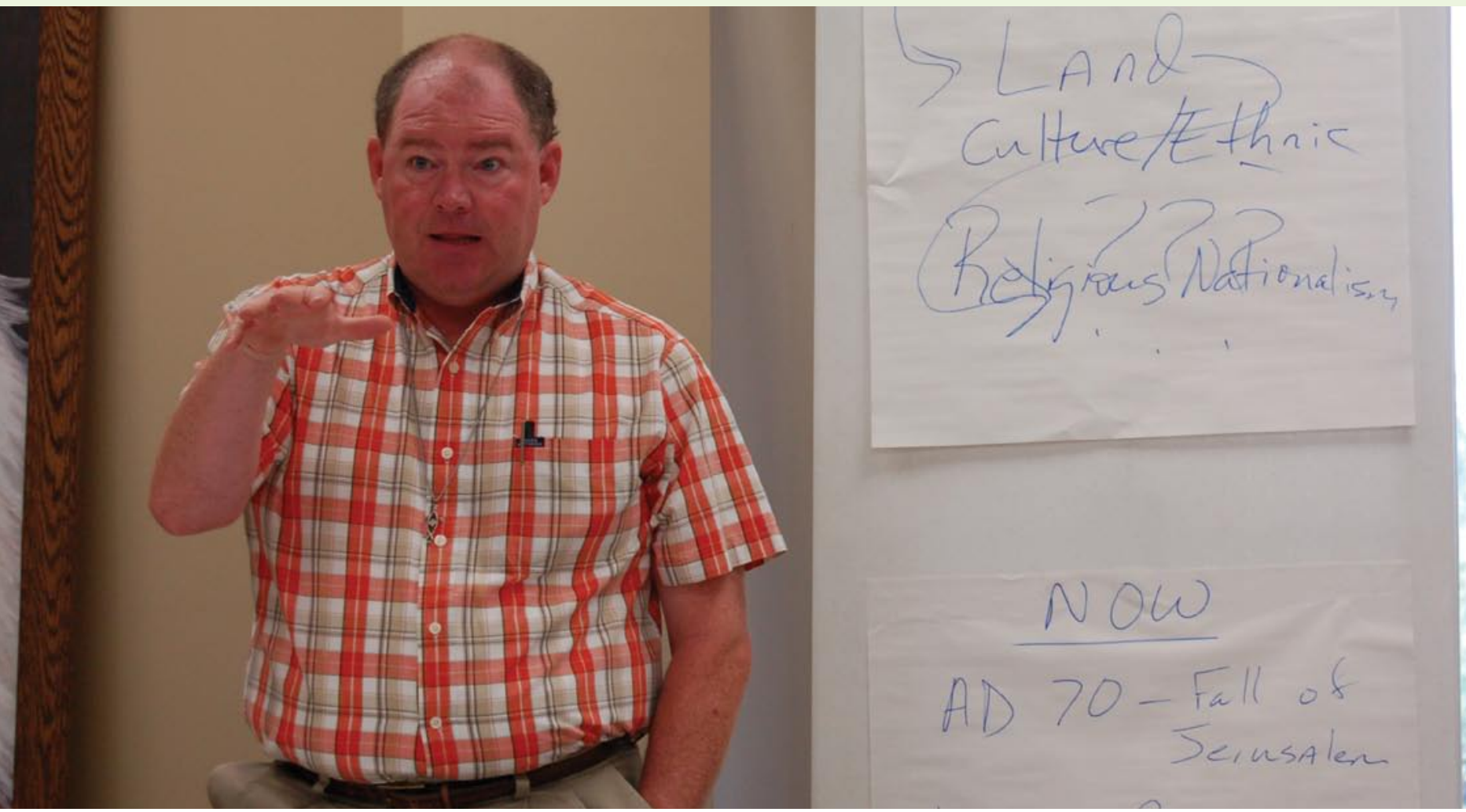

\section{Changing Church in the South: Religion and Politics in Elba, Alabama}

\author{
B Y J ULIE ARDERY
}

A long Highway 84 west of Elba, Alabama, (pop. 4,200) political signs"I Lucy" (gubernatorial candidate Lucy Baxley, that is), "Troy King, Alabama's Attorney General" and "Elect Lance Tindol Sheriff"share a grassy slope with "Ten Commandments," printed in full on cardboard and staked in the ground. Religious life and civic life, if not always consistent, are visibly contiguous in southeastern Alabama.

Census 2000 and a 2006 Gallup poll show Alabamians to be the most churchgoing people in the nation (tied with Louisianans and South Carolinians); and even by Alabama standards, Coffee County, where Elba is the county seat, ranks as super churchy. Among the 67 counties in the state, Coffee County showed the fifth highest rate of religious adherence.

A plurality of Alabamians were raised Southern Baptist, the largest Protestant denomination in the nation. In Alabama, alone, there are 3,148 Southern Baptist churches, according to the Association of Religious Data Archives, with more than 1,380,000 members. The next largest denomination, the United Methodist Church, claims fewer than one-third as many members. As for Elba, it's home to 24 Baptist churches and just two Methodist congregations.
Conventional wisdom and statistical evidence show Southerners to be considerably more conservative on social issues like gay marriage and abortion than others in the U.S. But in shifting one's vantage point from the aerial view of statistics to the streets of Elba, Alabama, the relationships among faith, politics and social values become far more nuanced and dynamic. In this Southern Baptist stronghold, the roles and expectations of women are changing, non-Baptists are moving here and looking for a church home, and a new faith community has emerged, disaffected with the established orthodoxy. While the Southern Baptist Convention dominates the rural South and is likely to shape political thinking here in the near future, recent experience in Elba suggests that within "the solid South" there are striations of questioning and even defiance. 


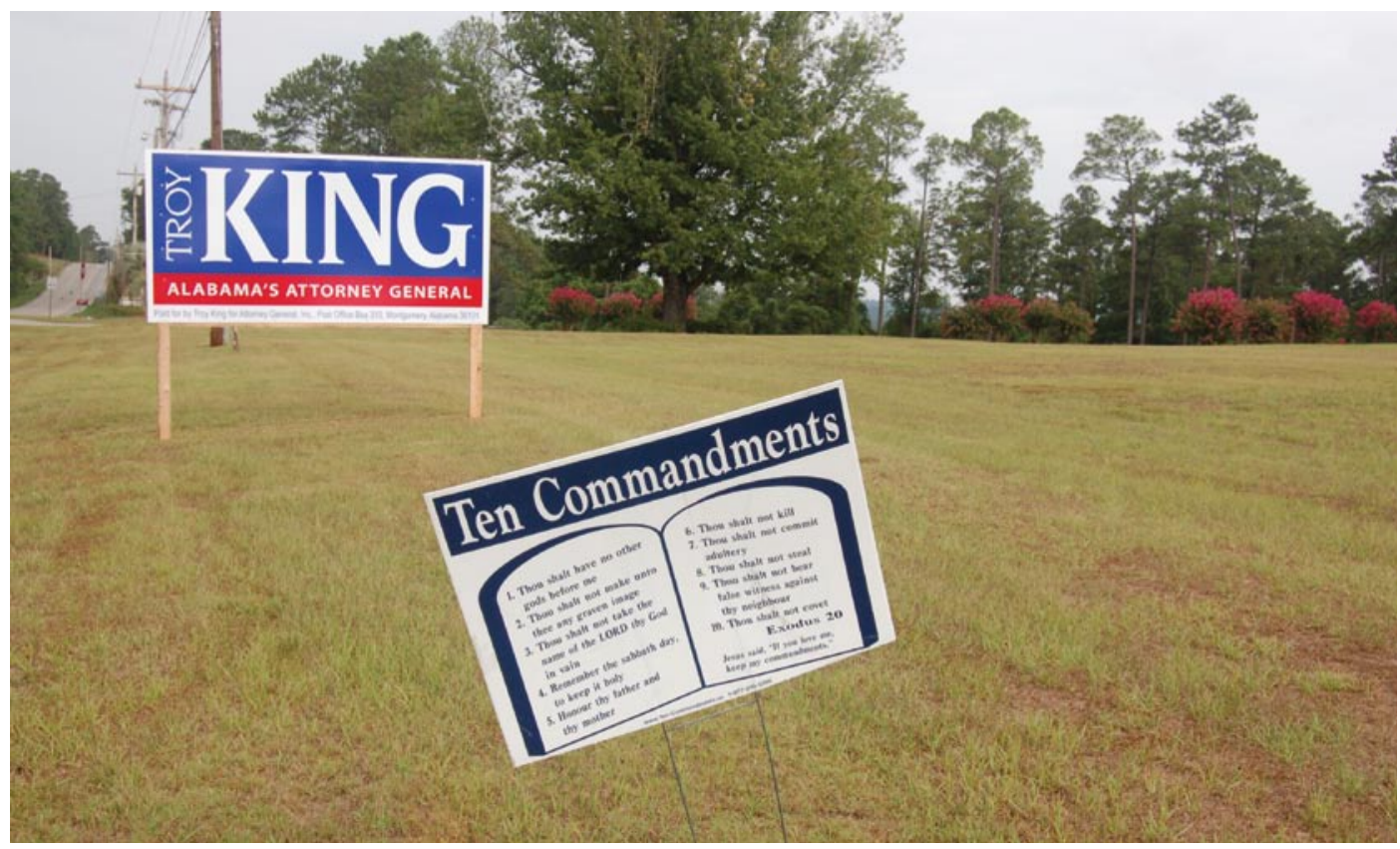

Historians of the South have gone so far as to call the Southern Baptist Convention (SBC) a "folk religion" in that its customs (like Wednesday evening services) and even its language ("born again") permeate so much of Southern life. "Our church is older than our politics," says Ferrin Cox, longtime publisher of the town's newspaper, the Elba Clipper.

African-American churches have, in many Southern cities and small towns, been hubs for political organizing and social activism. Rev. Keith Ellison, who pastors Elba's largest black congregation, the Harris Temple Church of God in Christ, says he regularly acknowledges visiting politicians from the pulpit and welcomes them to address his church membership, though not on Sunday mornings.

Until fairly recently, however, white Baptist congregations have left politics alone. The Episcopalians and Presbyterians controlled both money and government in most of the Old South; "The Baptists were isolated farmers with no influence," writes Kimble Forrister, director of the antipoverty group Alabama Arise, "so there was no point in their preachers developing such involvement." Separation of church and state was also an element of Baptist belief, and the barrier between them especially high for its longtime minority of Fundamentalists. They, in particular, eschewed the affairs of society-a fallen world - to focus on the urgent work of soul-saving. Forrister says that in his youth, the Baptist church's main foray into public issues was "stopping liquor sales, keeping counties dry. More recently, of course, they've become better organized."

Since the 1980s, in fact, this "better organized" Southern Baptist Convention has been key in turning whites of the formerly Democratic South into a reliably solid Republican block. "Fifteen years ago, no one would dare be a Republican," says Coffee County's Democratic Party Chairman Eddie Vaughan. "You had to run as a Democrat," remembers Mickey Murdock of Elba, "but when Reagan won, all the closet Republicans came out." Coffee County's current state representative and state senator are both
Democrats from Elba. But with the exception of "born-again" Southern Baptist Jimmy Carter in 1976, the county has voted Republican for president since 1972. In 2004, George W. Bush swept 74 percent of the Coffee County vote.

There are clear signs of Republican ascendancy in local politics, too. Mickey Murdock's wife, Liz, Elba's leading member of the Coffee County Republican Women, reports, "Our club has grown by leaps and bounds," and is now among the five largest GOP women's groups in the state. In the landslide of 2004, Republicans unseated two incumbent Democratic judges here. In the spring of 2006, lifelong Democrat Circuit Judge Thomas E. Head, seeking another term on the bench, switched his party affiliation.

"Even at the local level, elected officials are beginning to get identified with the national party, with whom the presidential candidate is," explains Head. "In the South, what people want to hear you say is that you adhere to traditional family values," and, increasingly, he says, there's a popular view "that you can't be a Democrat and do that. If I have to defend what I personally believe in, I can best do that as a Republican."

\section{A Crack Widens in Southern Baptist Culture}

Until the 1980s, moderates dominated the Southern Baptist Convention, with the Fundamentalist minority a loyal opposition. Liz Murdock participated as a voting "messenger" from Elba's First Baptist Church in several of the SBC's national gatherings. She contends that despite internal differences over any number of issues, "in the past, the convention was moving as one." That motion and tenor changed in the late 1970s, when a group of Fundamentalist members sloughed off the "other-worldliness" mission to strategize a takeover of the Southern Baptist Convention. Paul Pressler, a Baptist layman from Houston, and Paige 


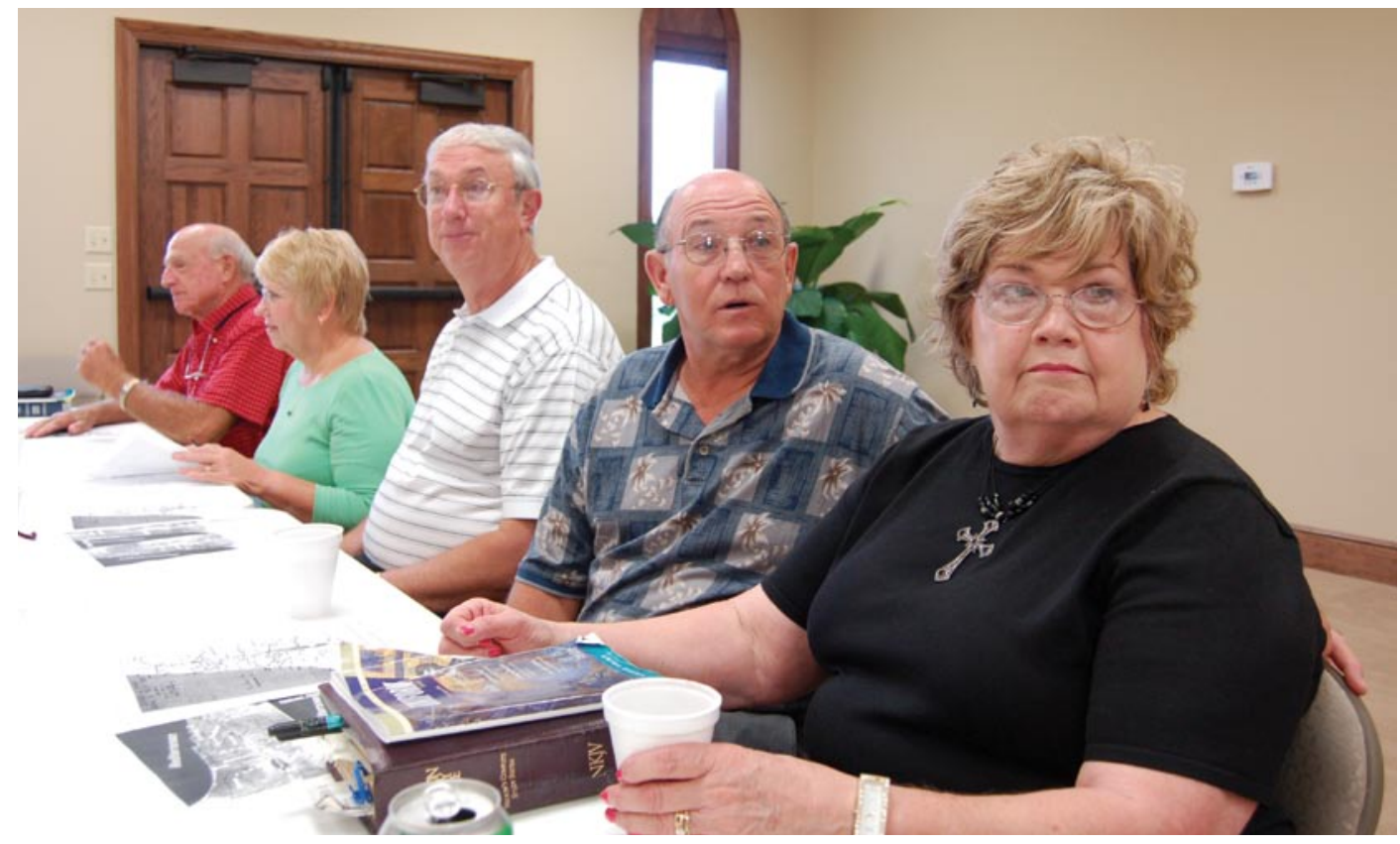

Elba residents attending Sunday School at Covenant Community Church, July 16, 2006. (l-r) J.R. Poole, Penny Glover, Bob Glover, Wendell Cotton, Myrna Cotton.

Patterson of Criswell Bible College in Dallas, with support from other extreme conservatives, determined that if they could elect Fundamentalist presidents of SBC over several consecutive years, they could stack the denomination's committees and gain control of every dimension of the church's work, from Sunday school literature, to mission funds, to seminary curricula. Murdock remembers a friend phoning her from the SBC national meeting during this period: "He said, 'Liz, they're bringing in people by busloads to get their people on the committees."

The strategy succeeded. Through alliances with secular leaders on the political right, such as Paul Weyrich of the National Committee for the Survival of a Free Congress and conservative fundraiser Richard Viguerie, as well as with the quasi-religious Moral Majority, founded in 1978, the SBC embarked on a political mission that unfolded over the next decade. The Reagan years, and Reagan's direct endorsement of the SBC's new activism in public affairs, emboldened the Southern Baptists' Fundamentalist leadership.

Because Baptist tradition favors the autonomy of local congregations and "the priesthood of the believer," the denomination historically has lacked both hierarchy and formal creeds. In 2000, however, the newly organized SBC voted to rewrite its basic statement of belief: the Baptist Faith and Message. In line with the SBC's new leadership, the revised statement underscored Fundamentalist tenets, in particular Biblical inerrancy and the subservience of women inside and outside the church. "While both men and women are gifted and called for ministry, the office of pastor is limited to men as qualified by Scripture," read the revised statement of faith. SBC also turned away from ecumenicism: "Inclusivism and pluralism in salvation," read the new statement, "compromise the gospel itself."

Once the revised Faith and Message was adopted, SBC required its missionaries to sign the statement or resign. "They started making everything very narrow," recounts Liz Murdock. "You were either on the far right or you were off course."
Moderates attempted to reclaim control of the SBC, pushing hard at the 1990 New Orleans convention. When that effort failed, Georgia pastor Daniel Vestal called a meeting of fellow Baptist moderates to Atlanta to discuss the future of the SBC and their place in it. On the basis of those discussions, the Cooperative Baptist Fellowship (CBF) was formed in 1991. CBF, which has not declared itself a separate denomination, now funds its own missionaries and has separately developed "partnerships" with seminaries and publishing houses. With only 1,500 churches, the Cooperative Baptist Fellowship has nowhere near the membership, wealth, or clout of the SBC, yet its very formation marks a crack in white Southern Baptist culture and the church's 15-year merger with the Republican Party. That crack is widening in, of all places, Elba, Alabama.

\section{Theological Differences Give Rise to a New Church in Elba}

Here in Elba, the First Baptist Church, for generations the town's largest congregation, has experienced a divide. Some 30 families, many of them the town's most well-to-do, have left to form Covenant Community Church, a new nondenominational congregation. The split certainly does not follow party lines-there are Republicans and Democrats in both congregations-but conversations with members of both churches show how social and political as well as theological differences among white Southern Baptists have intensified and boiled to the surface. These disparities have grown strong enough to establish new loyalties, new institutions, and new expressions of Christian conviction.

Mart Gray, 43, formerly the youth and music minister at First Baptist Church in Elba, had been part of the Cooperative Baptist Fellowship movement from the beginning. When an Alabama $\mathrm{CBF}$ was formed, he became its executive director and served as 


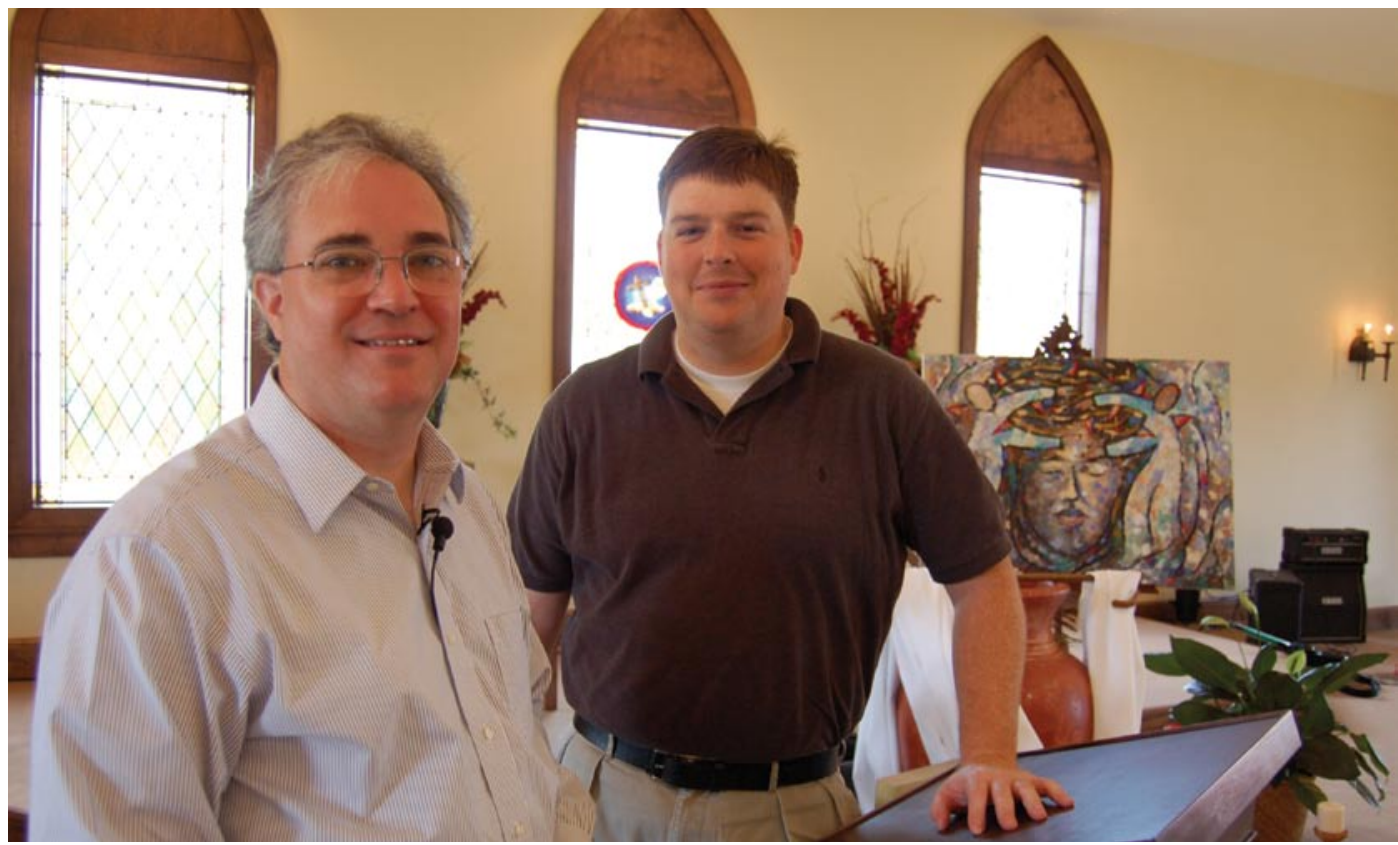

such for eight years. In that time, Gray became more and more interested in "planting" a new church.

"I felt like Elba needed a different voice," says Gray. "We had 57 flavors of vanilla. If you slice them theologically, they're very close together: a conservative, literal interpretation of the Bible. I felt a personal calling to try to do something different."

Gray had attended a leadership workshop at Wiregrass Training Institute, "They talked about the church being a stakeholder in the community," the sort of church he had in mind.

In January 2004, Gray met with ten couples, all members of First Baptist and personal friends, to discuss the idea of "doing church a little differently." Nine of them were ready to make a change. Gray presented a plan to about thirty people the first Sunday in February, expecting three months of planning and fundraising to follow. Instead, a house and land on the outskirts of Elba were swiftly donated, and the consensus was to have a sermon and worship service the next Sunday. "We put the plane together as we were flying it," says Gray. Covenant Community Church was underway. The congregation, now numbering about 120 people, broke ground in the summer of 2004, and its new church building was dedicated September 11, 2005.

Gray's leadership and his theology were in stark contrast with the more hardshell style of corrective pastoring. "Mart's a storyteller," says one teenager in the congregation. His family changed its membership from First Baptist to the Covenant Community Church early on. The First Baptist Church, he complains, had focused on "the dumbest things, like if you're watching the show Will \& Grace you're a bad person because it's about a homosexual." The 17-year-old says the message at his former church each Sunday was "in your face-this is something you shouldn't do. You're going to go to Hell. You never really left there and felt happy." For Jack Brunson, 49, the change came more slowly. "First Baptist was the church I was born into," he explains. But for his wife, Jane, the SBC's change in the Baptist Faith and Message was "the last straw." She was stunned at the idea that, as a woman, her role in the church was limited. Penny Glover, too, had "a hard time reconciling the lack of women's involvement, except for Sunday school and casseroles." She had been raised a Presbyterian in Kansas. Her husband Bob, from Chicago, grew up in the Lutheran faith. After moving to Elba, where there is neither a Presbyterian nor a Lutheran church, the Glovers joined First Baptist. Bob was elected a deacon six months later, but over time they saw the ecumenical spirit of the congregation waning.

Bob Glover says that at First Baptist the difference became palpable: “There was always this asterisk next to our name." After the church's moderate minister left, it was clear that the Glovers and one other couple had been admitted through "a loophole" that was rapidly closing. "It's really hard to take that what you've lived with your whole life isn't good enough," says Penny Glover.

The question of Biblical inerrancy, which had divided the SBC ten years prior, also split the Baptist congregation in Elba. Jack Brunson, who had been reluctant to leave his home church, was estranged by eight weeks of sermons on Genesis that set out, Brunson says, "to prove that the earth was only 6,000 years old."

July 4, 2004, a sermon on "The Greatness of America" described the nation's slide into immorality and challenged the parents present, especially those with college-age children, to "insist that all teachers be Christians." Brunson recounts that he and his wife Jane "got in the car and looked at each other and said, "We won't be going back for that."' Covenant Community Church is not formally affiliated with the CBF, yet the same issues that motivated Daniel Vestal and other moderates to distance themselves from the Southern Baptist Convention induced people in Elba to form a new nondenominational congregation. They were seeking, and appear to have found, ecumenicism, a stronger role for the laity (Gray himself, though formally ordained, considers himself a "lay preacher"), equal footing for women, and a more symbolic and contextual reading of scripture. 


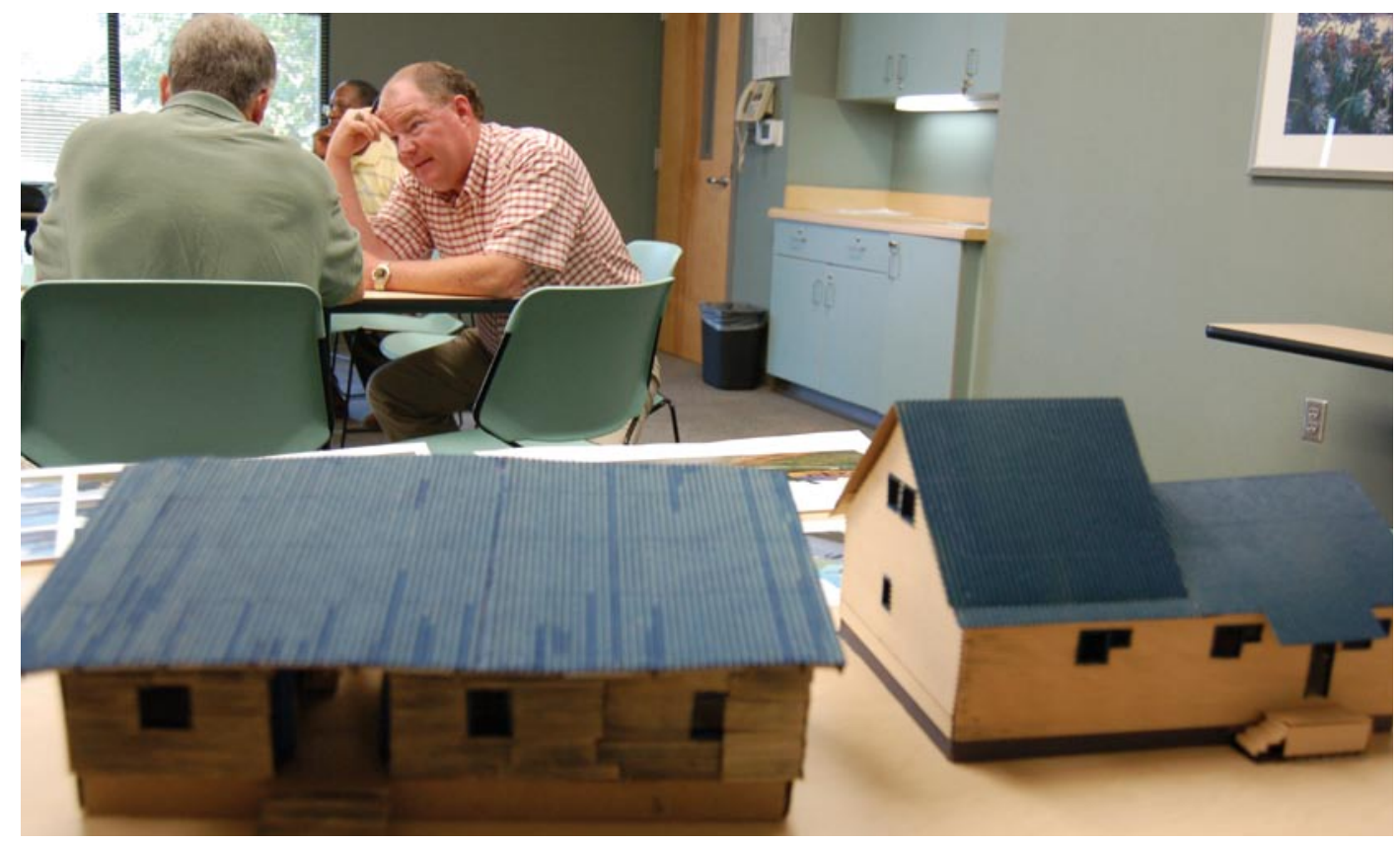

Elba Minister Mart Gray attending a meeting of the anti poverty program Sowing Seeds of Hope. Models of low-income housing in the foreground.

\section{Changing Perspectives on Church and State}

What may be the political ramifications of the tensions and changes occurring in Elba? Law prohibits the SBC and all taxexempt religious entities from formally aligning with political parties or candidates, yet the Southern Baptist Convention's president publicly endorsed George W. Bush in 2004. "It's not overstating the 2004 election results, both in the presidential and congressional contests, to say that traditional religious values won the day." So wrote Richard Land of the SBC's Ethics and Religious Liberty Commission; Land had high hopes for the denomination's "I vote values" website, created in 2004 to register voters and steer them toward Fundamentalist candidates.

Coffee County's Democratic Party chairman Eddie Vaughan reports that Fundamentalist "voter guides" have been distributed to local churches for "at least ten years" on the Sunday before elections. "The Christian Coalition is famous for it," says Vaughan. "They put printed material in all the Baptist churches in town and in the Methodist church," his own parish. "Sometimes they hand them out as you walk into the church," he notes. "I'm sure there's something in the Bible against that."

In his study of Southern Baptist clergy, political scientist James L. Guth writes that SBC conventions "have often resembled Republican rallies" in the years since 1984. Both Democratic and Republican SBC clergy became more active in support of presidential candidates in this period. But whereas activism among Democratic-voting clergy increased from 31 to 41 percent, rates of activism among GOP clergy grew from 40 percent to 63 percent. Guth writes, "This pattern is also reflected in general political activism: conservative and Republican ministers are more involved in a wide range of political actions than their more liberal and Democratic colleagues." ${ }^{1}$

\footnotetext{
${ }^{1}$ Guth, James L. 2005. "Southern Baptist Clergy, the Christian Right, and Political Activism in the South," in Politics and Religion in the White South, ed. Glenn Feldman. (Lexington: University Press of Kentucky), 191-94.
}

In Coffee County, too, religious moderates seem to be less politically explicit and engaged than Fundamentalists. Rev. Roger Miller, the First Baptist pastor who preaches regularly against abortion and homosexuality and stresses the literal truth of Genesis, says that religion and politics "very much overlap each other. People seem to have the same passions for both." Miller grew up in a military family, his parents both Democrats. "Now," he says, "they're Republicans," swayed by "a combination of things-ethics and moral issues," among them abortion, same sex marriage, and "big government."

"It used to be some things were written in stone," Miller laments. He was 14 when the Roe $v$. Wade ruling was handed down and remembers being caught up in the strong social movement against it. "I know as a kid growing up in a Baptist church, there was a lot of talk about this. This was a battle that we took on purposefully." Now Miller finds church-goers less willing to take up the fight: "Our culture has desensitized us," he says.

Miller raises such social issues vehemently and often in the pulpit at First Baptist. In contrast, members of Covenant Community Church seem vague, even uninterested, regarding political views within their congregation. "It never crossed my mind what the politics of the people at Covenant were," says Jack Brunson. "I've never heard politics even mentioned in church," Covenant member Bob Roberson declares, "I'm an independent."

Mart Gray himself has been a strong social activist. Prompted by friend and mentor Wayne Flynt, a historian at Auburn University, Gray helped to develop Sowing Seeds of Hope, an antipoverty program in the Alabama Black Belt. Yet Gray has not foisted this social mission on the Covenant congregation. Nor, as pastor, does he directly address social issues such as same-sex marriage or use phrases like "Biblical inerrancy." That terminology, he says, tends to exact declarations and attach labels "for" and "against." Gray says his goal is "to be an honest broker of conversations. Let those things come up as they will." 


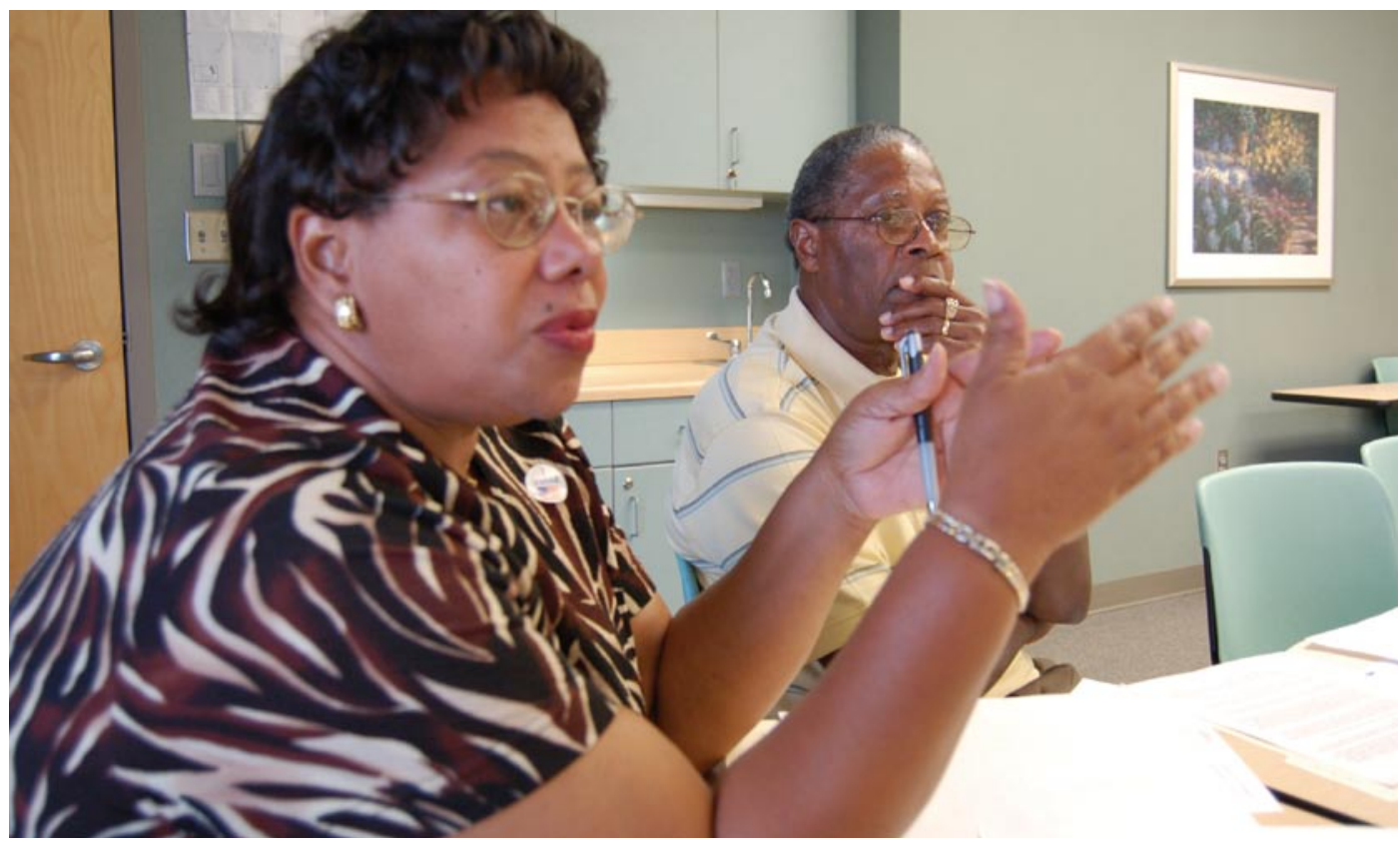

And it's likely that they will. As people from other regions, like the Glovers, continue to pour southward, there will be no avoiding denominational differences even among Christians. Family structures, too, are changing. "There were three unwed mothers in church Sunday," one member of Covenant Community Church relayed, with a mixture of shock and pride. According to the 17-year-old whose family moved its membership to Covenant, there are homosexuals who attend the church. "Everybody knows that," he says. "It's never brought up."

Juli Parrish has a blended family. She says her husband, raised in a strict Southern Baptist church near Elba, had to resign his deaconship after his divorce. As a consequence, she says, he became, "disenchanted with organized religion," She was raised Southern Baptist, also, in the nearby town of Troy, "But there was a lot of Baptist doctrine that I never really swallowed." In contrast, Parrish says, Covenant Church "has a lot more conversation, discussion. I'm not going to feel like an outsider. It's a nonjudgmental place where most people can be comfortable."

Mart Gray contends he has no desire to compete with Fundamentalist churches in Elba or elsewhere. "My goal is to reach people who will never be reached by that," he says. To build a "post-denominational" congregation such as Covenant in a small Southern town, "you're under a lot of scrutiny," and working against a number of stereotypes as well. "The myth is that rural people aren't ready for this," says Gray. "They ARE ready."

So long cast as traditionalists, the Southerners in Elba are loosening the apron strings that have bound them historically to party and denomination. Like Judge Thomas Head, who became a Republican better to "defend my position" (and, he hopes, retain his seat on the bench), churchgoers are acting with increasing pragmatism. As "free-agents," they are walking away from institutions where, for one reason or many, they can no longer "be comfortable." In the process, social organizations, whether the Republican Women of Coffee County, Covenant Community Church or First Baptist, may become more homo- geneous, as like-minded people self-segregate. Mickey Murdock, treasurer of Elba's First Baptist Church in 2006, admits, "I think as a congregation we are more fundamentalist than we were ten years ago." Why? "A lot of moderates left the church."

Mart Gray sees the Southern Baptist Convention's turn to the political right not so much as a values-based redirection but the consolidation of power. From the "poor farmers" Kimble Forrister described, Southern Baptists after World War II had grown into far greater numbers and affluence. "All of a sudden, they've got wealth, they've got influence, and it's a different day," Gray says. "You're on the President's rolodex." As Gray sees it, the more powerful SBC then initiated a "top-down" authority structure to consolidate and expand its own influence: "They were just leveraging what they had."

A look around Elba, Alabama, suggests that faith and politics in the South, rather than fused predictably together, may be more open questions. Especially now, as women, notably Republican women, assume greater public prominence, as new residents arrive with their religious heritages and social convictions in tow, and as people increasingly seek welcoming fellowships, the authority of exclusionary institutions like the Southern Baptist Convention is waning. And its challenge seems to be coming not from a liberal counterpunch, but from an opposition more diffuse and circumspect.

"When you use the power of religion to support your political position, it's a very combustible blend. You have to be careful," says Mart Gray. "I always vote on the basis of my religious convictions, but never with the certainty I'm voting 'God's way."”

Author's note: An earlier version of this essay wrongly stated that Coffee County's state senator did not attend a church. The author regrets this error. State Sen. Jimmy Holley attends the College Avenue Church of Christ in Enterprise, Alabama. 


\section{Related Readings}

Hamilton, Lawrence. 2006. Rural Voting in the 2004 Election. Durham, NH: The Carsey Institute.

Dillon, Michele and Sarah Savage. 2006. Values and Religion in Rural America: Attitudes Toward Abortion and Same-Sex Relations. Durham, NH: The Carsey Institute.

Both reports available online at http://www.carseyinstitute.unh. edu/publications.html

\section{About the Author}

Julie Ardery, a Ph.D. sociologist, has written about American culture and art for The American Prospect, Texas Monthly, the Texas Observer, and American Craft. Her book The Temptation, about the fascination of affluent Americans for folk art, was published in 1998 by University of North Carolina Press. 


\section{CARSEY \\ I N S T I T U T E}

\section{BUILDING KNOWLEDGE FOR Rural America's Families And Communities in the 21ST CENTURY}

Carsey Institute

University of New Hampshire Huddleston Hall

73 Main Street

Durham, New Hampshire

03824-3563

$603-862-2821$

603-862-3878 (FAX)

www.carseyinstitute.unh.edu

The Carsey Institute Reports on Rural America are supported by the Annie E. Casey Foundation's initiative to strengthen rural families, the Ford Foundation, and W.K. Kellogg Foundation.

Photos by Julie Ardery.

Pictured on the front: Pastor Mart Gray leads an adult Sunday school class at Covenant

Community Church, a new non-denominational congregation in Elba, Alabama.

\section{ANIVERSITY}

